AperTO - Archivio Istituzionale Open Access dell'Università di Torino

\title{
3D Geological visualizations of geoheritage information in the Monviso Massif (Western Alps)
}

\section{This is the author's manuscript}

Original Citation:

Availability:

This version is available http://hdl.handle.net/2318/1566216

since 2018-06-14T09:33:05Z

Published version:

DOI:10.3301/ROL.2016.52

Terms of use:

Open Access

Anyone can freely access the full text of works made available as "Open Access". Works made available under a Creative Commons license can be used according to the terms and conditions of said license. Use of all other works requires consent of the right holder (author or publisher) if not exempted from copyright protection by the applicable law. 


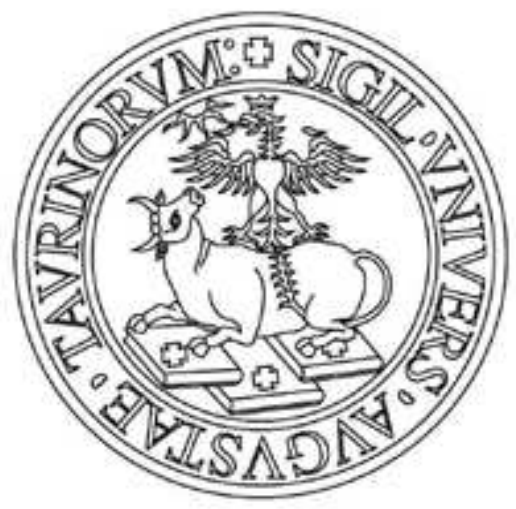

\section{UNIVERSITA' DEGLI STUDI DI TORINO}

This is an author version of the contribution published on:

Questa è la versione dell' autore dell'opera: Balestro, G. et al. (2016) - Rendiconti online della Società Geologica Italiana, v.39, 81-84 doi: 10.3301/ROL.2016.52

The definitive version is available at:

La versione definitiva è disponibile alla URL:

http://rendiconti.socgeol.it/ 


\title{
3D Geological visualizations of geoheritage information in the Monviso Massif (Western Alps)
}

\author{
Gianni Balestro $^{(\mathrm{a})}$, Roberto Cassulo ${ }^{(\mathrm{b})}$, Andrea Festa ${ }^{(\mathrm{a})}$, Gianfranco Fioraso ${ }^{(\mathrm{c})}$, Marco Giardino ${ }^{(\mathrm{a})}$, Gabriele Nicolò ${ }^{(\mathrm{b})}$ \& Luigi \\ Perotti $^{(a)}$
}

(a) Università di Torino, Dipartimento di Scienze della Terra, Vial Valperga Caluso, 35, 10125, Torino, Italy. Email: gianni.balestro@unito.it

(b) Arpa Piemonte, Via Pio VII, 9, 10135, Torino, Italy

(c) CNR, Istituto di Geoscienze e Georisorse, Vial Valperga Caluso, 35, 10125, Torino, Italy.

Document type: Short note. Manuscript history: received xx xxxx xxxx; accepted xx xxxx xxxx; editorial responsibility and handling by xxxxxx.

\begin{abstract}
Geoheritage information comes from areas that, for their peculiar features, are of geological interest (i.e. geosites). An important activity for geosites management consists of developing and applying useful digital tools for sharing information. The PROGEO-Piemonte (PROactive management of GEOlogical heritage in the PIEMONTE region) is an example of a project wherein different IT applications have been implemented for collecting, storing and spreading geoheritage information. The most important of these applications consists of building 3D visualizations of geological features through the Arpa Piemonte Geoportal, which hosts a GIS-based 3D viewer loading high resolution DTM and aerial images. Lithostratigraphic, structural and geomorphological features occurring in the Monviso Massif in the Western Alps are selected from geological map databases, processed by GIS tools and draped over the terrain model. 3D visualizations give realistic and easy-to-read representations of geology around geosites or along geological trails, and contribute to overcome problems that commonly occur in transferring contents of geological maps to non-expert users.
\end{abstract}

KEY WORDS: geoheritage, GIS, Monviso meta-ophiolite, tectonic contact, glacial landform.

\section{INTRODUCTION}

Geoheritage information corresponds to geological fetaures and sites (i.e. geosites) that, for their peculiar characteristics, are scientifically important and can be used both for research, geoconservation and geotourism. An important activity for management of these kind of data consists of developing and applying useful digital tools for storing, processing and sharing information (Cayla, 2014).

In our approach (Balestro et al., 2015a), IT applications to the frame of geoheritage and geosites, consists of three main working steps which correspond to (i) digital geological mapping, (ii) realization of geological map databases and (iii) building of 3D geological visualizations.

The first step consists of mapping geology around geosites and collecting geoheritage data by means of GPS technology and GIS (mobile) applications loaded on rugged handheld devices. Field data are then stored in map databases and processed by GIS (desktop) tools. In the third step, 3D geological visualizations are built through a GIS-based 3D viewer (Fig.1) that draps meaningful geological features over digital terrain models and aerial images. These 3D visualizations have not the capabilities of real 3D geological models (i.e. numerical models that actually allow building and checking geometry of geological units; see e.g. Zanchi et al., 2009), but allow giving realistic and easy-to-read representations of geology around geosites or along geological trails.

\section{THE PROGEO-PIEMONTE PROJECT AND THE MONVISO MASSIF}

Digitalization and 3D geological visualizations of geoheritage information have been particularly developed in the frame of the PROGEO-Piemonte (PROactive management of GEOlogical heritage in the PIEMONTE region) project. The latter aims to inventory geosites in the Piemonte region (NW Italy) for promoting both their conservation and divulgation. Following the methodological approach of the ProGEO association (http://www.progeo.se), the project and its multidisciplanry group also aims to develop new techniques for recognizing and managing the rich geodiversity of the Piemonte region at different scales (Giardino et al., 2012). Within the project, nine geothematic areas have been chosen, each one being characterized by high potential for scientific studies and enhancement of public understanding of science. One of the PROGEO geothematic area is the Monviso Massif (Rolfo et al., 2014a), which corresponds to one of the most outstanding symbol of the Alps lately recognized as a Biosphere Reserve (MAB Programme of UNESCO).

The Monviso Massif is particularly characterized by the occurrence of well-exposed meta-ophiolite sequences and spectacular glacial landforms. All along these geological features an Ophiolite Geopark with different geological trails has been developed in the upper Po Valley (Rolfo et al., 2014b). The main geological trail allows to walk $i$ ) across an 


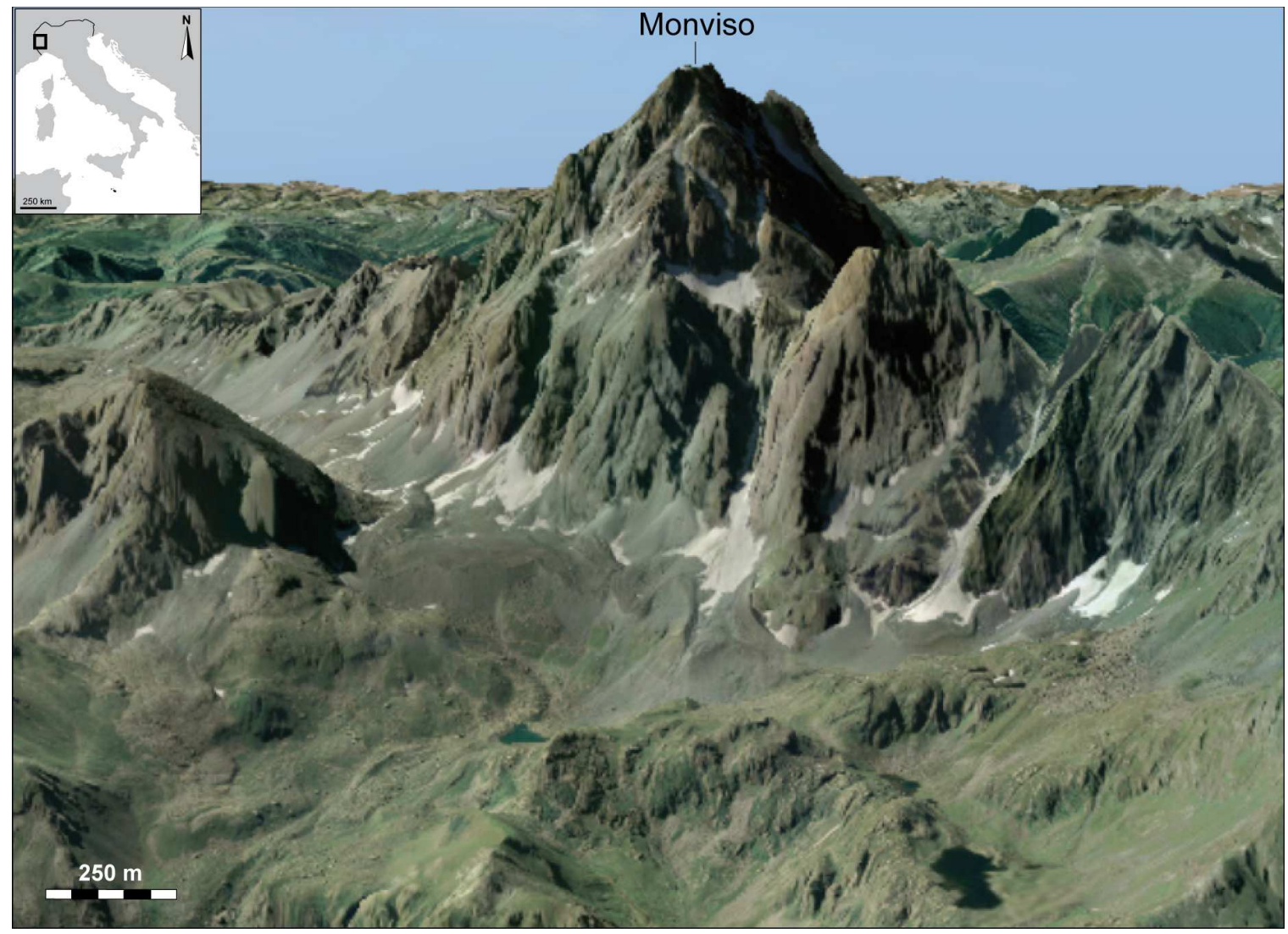

Fig. 1 -3D virtual view (looking South) of the Monviso Massif.

ancient ocean (i.e. the Monviso Meta-ophiolite Complex; Balestro et al., 2014; Balestro et al., 2015b) and ii) on glacial landforms related both to the Last Glacial Maximum and to the Little Ice Age (Balestro et al., 2011; Balestro et al., 2013).

The Monviso Meta-ophiolite Complex is a remnant of the Jurassic Western Tethys that was subducted and stacked in the axial sector of the Western Alps. During Alpine tectonic, original ophiolite sequences (i.e. serpentinized peridotite, gabbros, basalt and sediments), were metamorphosed under eclogitic conditions and dismembered into different tectonic units that characterize the inner architecture of the Monviso Meta-Ophiolite Complex.

The present-day morphology of the Monviso Massif mainly results from glacial modeling during Pleistocene glaciations. Glacial deposits related to the Last Glacial Maximum and to the subsequent glacier retreat are in particular extensively preserved at the head of the Po Valley.

\section{D GEOLOGICAL VISUALIZATIONS}

Meaningful lithological, structural and geomorphological features occurring in the Monviso Massif are selected from geological map databases, processed by GIS tools and draped over terrain models through the Arpa Piemonte Geoportal (http:// http://webgis.arpa.piemonte.it/geoportale). The latter hosts a GIS-based 3D viewer that loads high resolution DTM (5 meters) and aerial images $(50 \mathrm{~cm} /$ pixel), and enables 3D visualizations of landscapes (Fig. 1) and geoheritage information.

An example of meaningful geomorphological feature corresponds to the glacial landforms occurring at the base of the Monviso north face (Fig.2). The boundary between different glacial deposits and the related moraine ridges are directly imported in the 3D viewer. Draping of these linear features over aerial images supports visualization of geomorphology from different point of views (and distances).

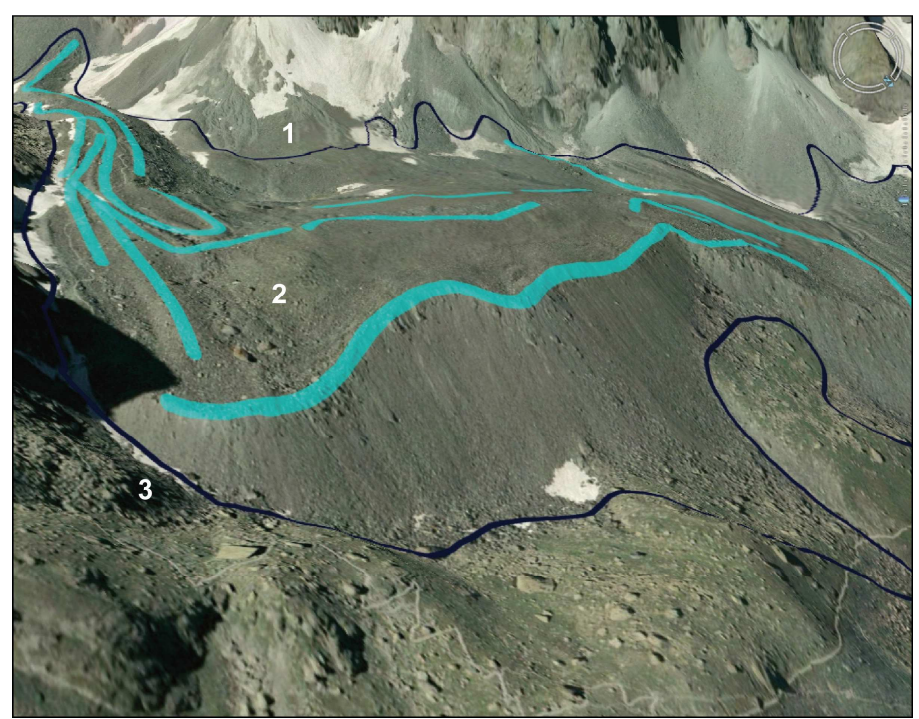

Fig. $2-3 \mathrm{D}$ visualization of the moraine ridges (light blue line) occurring at the base of the Monviso north face. The dark blue line shows the boundary talus deposits (1), glacial deposits of the Little Ice Age (2) and glacial deposits of the Last Glacial Maximum (3). 


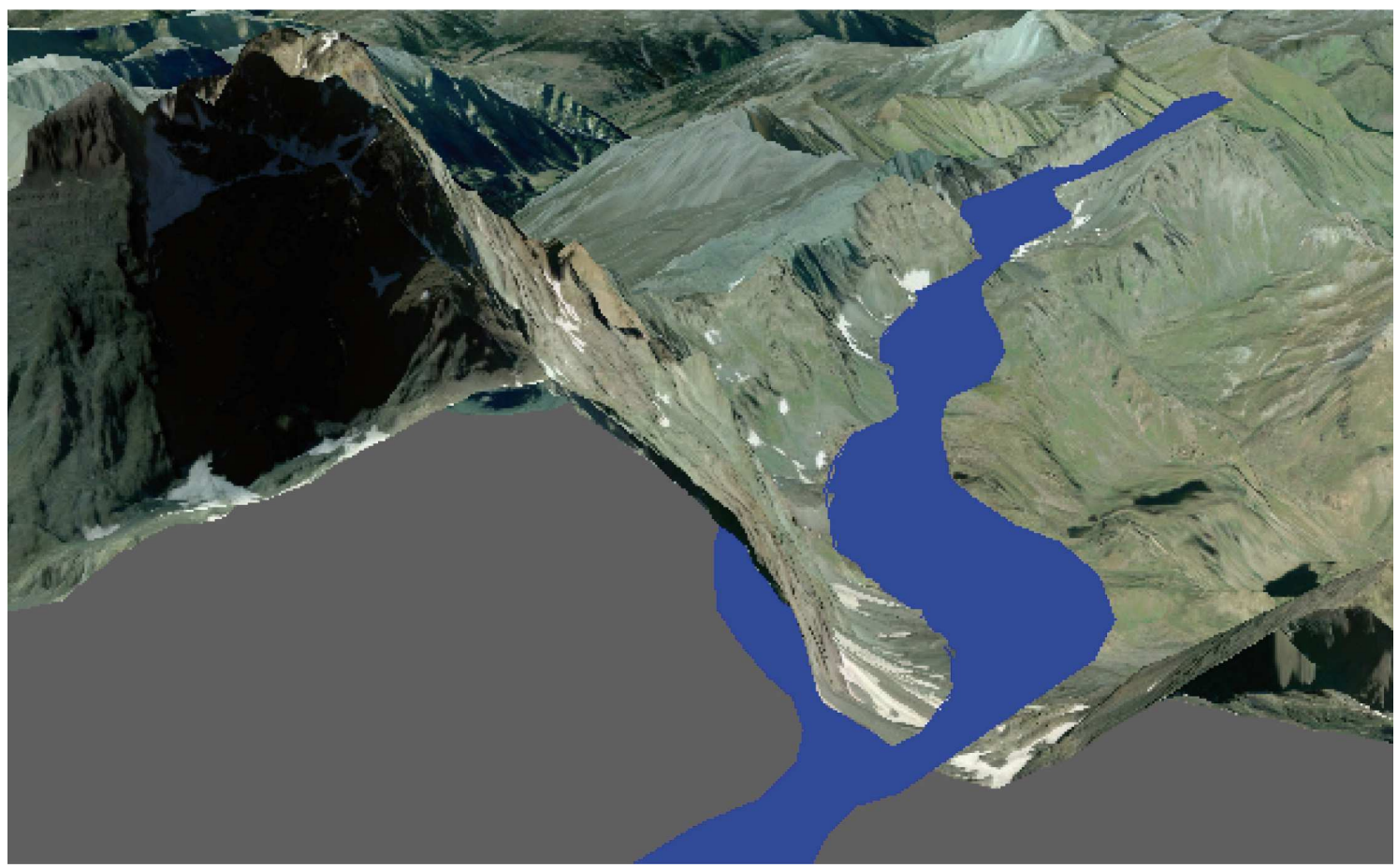

Fig. 3 - 3D visualization (looking North) of the main tectonic contact (blue surface) occurring within the Monviso Meta-ophiolite Complex. Underground view of the plane is obtained by creating a hole in the terrain model.

An example of meaningful structural feature is the tectonic contact that separates the two tectonometamorphic units occurring within the Monviso Meta-Ophiolite Complex. The tectonic contact correspond to a linear features that is extracted from the map database, transformed into a 3D plane through a dedicated script and imported in the 3D viewer.

The workflow for the generation of this $3 \mathrm{D}$ plane consists of different steps that include (i) transformation of the original linear feature into a new polygon feature through a buffer operation, (ii) generation of a new 3D polygon through DTM interpolation, (iii) generation of a new 3D point layer from vertices of the 3D polygon, (iv) correction of the " $\mathrm{z}$ " values of vertices according to the dip of the plane, and (v) transformation of the 3D point layer into a new linear layer, from which a final 3D polygon representative of the tectonic contact is created.

The projection of the generated 3D polygon in the 3D viewer allows both surface and underground visualization of the tectonic contact (Fig. 3). In this way, structures can be easily represented and explained also to non-experts users.

\section{CONCLUSIONS}

Sharing and spreading of geoheritage information are nowadays widely enhanced by use of IT applications. GISbased 3D visualizations particularly allow building realistic and easy-to-read representations of geology around geosites or along geological trails.

Virtual observation of landscapes and geomorphology from different point of view and at different scale, is a useful integration of real-world observations.

Moreover, 3D visualizations enable easy-to-read representations of complex and inferred map-scale structures, so that the problems that commonly occur in transferring contents of geological maps to non-expert users can be (partly) overcome.

Although these visualizations have not the capabilities of real 3D geological models, they are also useful for field geologists that can easily visualize their map interpretations (and related uncertainties).

\section{ACKNOWLEDGMENTS}

Research funded by the University of Torino and Compagnia di San Paolo Bank Foundation (Project: "PROactive Management of GEOlogical Heritage in the PIEMONTE Region", grants to $\mathrm{M}$. Giardino).

\section{REFERENCES}

Balestro G., Fioraso G. \& Lombardo B. (2011) - Geological map of the upper Pellice Valley (Italian Western Alps). Journal of Maps, 2011, 634-654.

Balestro G., Fioraso G. \& Lombardo B. (2013) - Geological map of the Monviso massif (Western Alps). Journal of Maps, 9 (4), 623-634, DOI: 10.1080/17445647.2013.842507.

Balestro G., Lombardo B., Vaggelli G., Borghi A., Festa A., \& Gattiglio M. (2014) - Tectonostratigraphy of the northern Monviso Meta-ophiolite Complex (Western Alps). Italian Journal of Geosciences, 133 (3), 409-426. 
DOI:10.3301/IJG.2014.13

Balestro G., Cassulo R., Fioraso G., Nicolò G., Rolfo F., Bonansea E., Cadoppi P., Castelli D., Ferrando S., Festa A., Groppo C., Morelli M., Mortara G. \& Mosca P. (2015a) - IT applications for sharing geoheritage information: the example of the geological and geomorphological trail in the Monviso massif (NW Italy). Rendiconti Online della Società Geologica Italiana, 34, 85-88.

Balestro G., Festa A. \& Tartarotti P. (2015b) - Tectonic significance of different block-in-matrix structures in exhumed convergent plate margins: examples from oceanic and continental HP rocks in Inner Western Alps (northwest Italy). International Geology Review, 57 (5-8), 581-605, DOI: 10.1080/00206814.2014.943307

Cayla N. (2014) - An Overview of New Technologies Applied to the Management of Geoheritage. Geoheritage, 6 (2), 91-102.

Rolfo F., Benna P., Cadoppi P., Castelli D., Favero-Longo S.E., Giardino M., Balestro G., Belluso E., Borghi A., Cámara F., Compagnoni R., Ferrando S., Festa A., Forno M.G., Giacometti F., Gianotti F., Groppo C., Lombardo B., Mosca P., Perrone G., Piervittori R., Rebay G. \& Rossetti P. (2014a) The Monviso massif and the Cottian Alps as symbols of the Alpine chain and geological heritage in Piemonte, Italy. Geoheritage. DOI: 10.1007/s12371-014-0097-9.

Rolfo F., Balestro G., Borghi A., Castelli D., Ferrando S., Groppo C., Mosca P. and Rossetti P. (2014b). The Monviso Ophiolite Geopark, a Symbol of the Alpine Chain and Geological Heritage in Piemonte, Italy. G. Lollino et al. (eds.), Engineering Geology for Society and Territory, 8, 239-243, DOI: 10.1007/978-3-319-09408-3-40.

Zanchi A., De Donatis M., Gibbs A., Mallet J. (2009) Imaging geology in 3D, Computer \& Geoscience, 35, 1-3. 